\title{
A Short Report on the Extent of Stone Handling Behavior Across Otter Species
}

\author{
Elisa Bandini ${ }^{1 *}$, Margherita Bandini ${ }^{2}$, \& Claudio Tennie $^{1}$ \\ ${ }^{1}$ Department of Early Prehistory and Quaternary Ecology, University of Tübingen, Tübingen, Germany \\ ${ }^{2}$ Independent researcher \\ *Corresponding author (Email: elisa-bandini@hotmail.it)
}

Citation - Bandini, E., Bandini, M., \& Tennie, C. (2021). A short report on the extent of stone handling behavior across otter species. Animal Behavior and Cognition, 8(1), 15-22. https://doi.org/10.26451/abc.08.01.02.2021

\begin{abstract}
Animal stone-handling behavior ( $\mathrm{SH}$ ) has been recorded in detail only in primates, mainly across macaque species. The purpose(s) of SH are still unknown, yet various hypotheses have been suggested, including that it is a misdirected behavior when hungry and/or a play behavior that aids individuals' motor and stone tool-use development. SH has also been observed across both wild and captive otter species, but no overview report of the extent of this behavior across otter species has been published yet. To fill this gap in the literature, we contacted wild and captive otter researchers and keepers to enquire directly on SH in the species they work with. We accepted anecdotal reports in this first review of the behavior. Using the reports and anecdotes thus obtained, we compiled the first list of otter species that show SH. We found that most (10 out of 13) of currently known otter species practice $\mathrm{SH}$. Therefore, similarly to macaques, $\mathrm{SH}$ is also common in otters and occurs in the majority of species. Future studies should focus on replicating these findings and further investigating the potential functions and selection pressures of SH in otters and other animal species.
\end{abstract}

Keywords - Otters, Stone handling, Stone manipulation, Stone play, Otter stone tool-use

Object-orientated play behaviors, defined as "the spontaneous, repeated, seemingly relaxed, incompletely functional, and usually solitary manipulation of inanimate objects" (Pelletier et al., 2017, p. 3), are observed in various species of animals (e.g., Power, 1999). One type of object-orientated play behavior is stone handling behavior (henceforth: $\mathrm{SH}$ ). SH involves the manipulation of stones in various, not obviously goal oriented ways. Leca and colleagues (2011) defined SH as "spontaneous stone-directed non-instrumental manipulative behavior" (p. 61). SH includes behaviors such as "rock juggling" (Allison et al., 2020) and/or "gathering stones into a pile, clacking stones together, or repeatedly pounding a stone on a substrate" (Gunst et al., 2007, p. 254). More generally, various stone-related activities may be included under the SH umbrella (eight categories were identified by Huffman \& Quiatt, 1986).

The most detailed records of SH in animals come from macaques, especially from Japanese macaques (Macaca fuscata; e.g., Huffman \& Nahallage, 2007; Huffman \& Quiatt, 1986; Leca et al., 2008). SH is also observed in rhesus macaques (Macaca mulatta; Nahallage \& Huffman, 2012), longtailed macaques (Macaca fascicularis; Bandini \& Tennie, 2018; Pelletier et al., 2017; Tan, 2017) and Taiwanese macaques (Macaca cyclopis; Pelletier et al., 2017). However, SH has also been observed in wild and captive otters. Indeed, a recent article by Allison and colleagues (2020) provides one of the first in-depth investigation into SH in other animal species, namely in two species of captive otters (Lutrogale perspicillata and Aonyx cinereus; Allison et al., 2020). 
The field of animal cognition seems to be somewhat biased towards observations of primates, perhaps due to their closer phylogenetic ties to humans (van Horik \& Madden, 2016). However, studying the cognition of other species is just as important, and can provide a more complete picture of animal, and potentially even human, cognition (Pelletier et al., 2017). Therefore, the aim of this short report is to describe, to the best of our knowledge for the first time, the extent of SH across all currently known species of otters (including both wild and captive otters). We provide a list of species in which SH has been observed so far as a general basis for future in-depth studies (similar to the ones carried out by Allison et al., 2020).

\section{Otter Species}

Currently, there are 13 different species of otters recognized in the wild, distributed across all continents except Oceania, Antarctica and the Arctic (see Table 1; in alphabetical order: Aonyx capensis; Aonyx cinereus; Aonyx congicus; Enhydra lutris; Hydrictis maculicollis; Lontra canadensis; Lontra felina; Lontra longicaudis; Lontra provocax; Lutra lutra; Lutra sumatrana; Lutrogale perspicillata; Pteronura brasiliensis; Duplaix \& Bandini, 2016).

All otter species present distinct ethological and morphological traits (see Table 1). They are, however, similar in their dietary requirements and are considered opportunistic carnivores, eating a wide range of prey species that they forage and hunt for using their sensitive vibrissae and tactile paws (Kruuk, 2006).

\section{Otter Tool-use}

Enhydra lutris (sea otter) is the only species of otters currently known to use stones as tools to access prey. Enhydra lutris uses rocks and other hard objects as hammers to pound open invertebrate prey (Fujii et al., 2015). This behavior has been compared to long-tailed macaque (Macaca fascicularis aurea) stone tool use - pound-hammering behavior - a behavior in which wild long tailed macaques use stones to crack open shelled food sources (Fujii et al., 2017). Enhydra lutris will likewise use stones, acquired during foraging (Perry, 2012), as "hammers" to smash the hard exoskeleton or shells of their food items (mollusks, crustaceans and other invertebrates). This is done by raising the stone above their heads with their paws whilst floating on their backs and bringing it down, with considerable force, on the invertebrate lying on another stone on their chest (Haslam et al., 2019). However, Enhydra lutris also uses stones as anvils to pry open their prey or to hit mollusks, such as abalone, from underwater and surface rocks (Riedman \& Estes, 1990). Stone tool-use has not yet been observed in any other wild or captive otter species. 
Table 1

Distribution and Main Characteristics of Wild Otter Species

\begin{tabular}{|c|c|c|c|c|c|}
\hline Otter species & Distribution & Social behavior & Foraging habitat & Prey preferences & $\begin{array}{l}\text { Main morphological } \\
\text { characteristics }\end{array}$ \\
\hline Aonyx capensis & $\begin{array}{l}\text { Sub-Saharan } \\
\text { Africa }\end{array}$ & $\begin{array}{l}\text { Small family groups } \\
\text { (3-10 individuals) }\end{array}$ & $\begin{array}{l}\text { Freshwater and } \\
\text { coastal habitats }\end{array}$ & $\begin{array}{l}\text { Crustaceans, } \\
\text { mollusks, frogs, } \\
\text { insects, invertebrates }\end{array}$ & $\begin{array}{l}12-19 \mathrm{~kg} \\
\text { Absence of claws and } \\
\text { reduced webbing on } \\
\text { paws }\end{array}$ \\
\hline Aonyx cinereus & $\begin{array}{l}\text { Southeast Asia } \\
\text { and India }\end{array}$ & $\begin{array}{l}\text { Large family groups } \\
\text { (up to } 30 \\
\text { individuals) }\end{array}$ & $\begin{array}{l}\text { Slow moving } \\
\text { freshwater } \\
\text { systems, rice } \\
\text { paddies }\end{array}$ & $\begin{array}{l}\text { Crustaceans, } \\
\text { mollusks, insects }\end{array}$ & $\begin{array}{l}2-5 \mathrm{~kg} \\
\text { Absence of claws and } \\
\text { reduced webbing on } \\
\text { paws }\end{array}$ \\
\hline Aonyx congicus & Central Africa & $\begin{array}{l}\text { Small family groups } \\
\text { (3-10 individuals) }\end{array}$ & $\begin{array}{l}\text { Slow moving } \\
\text { freshwater } \\
\text { systems }\end{array}$ & $\begin{array}{l}\text { Mollusks, } \\
\text { crustaceans, } \\
\text { earthworms, frogs }\end{array}$ & $\begin{array}{l}12-17 \mathrm{~kg} \\
\text { Absence of claws and } \\
\text { reduced webbing on } \\
\text { paws }\end{array}$ \\
\hline Enhydra lutris & $\begin{array}{l}\text { North Pacific } \\
\text { Ocean }\end{array}$ & $\begin{array}{l}\text { Large, same sex } \\
\text { groups (up to } 100 \\
\text { individuals) }\end{array}$ & $\begin{array}{l}\text { Kelp forests and } \\
\text { rocky coasts }\end{array}$ & $\begin{array}{l}\text { Invertebrates, } \\
\text { mollusks, crustaceans }\end{array}$ & $\begin{array}{l}23-36 \mathrm{~kg} \\
\text { Absence of blubber, } \\
\text { thick webbing on paws }\end{array}$ \\
\hline $\begin{array}{l}\text { Hydrictis } \\
\text { maculicollis }\end{array}$ & $\begin{array}{l}\text { Sub-Saharan } \\
\text { Africa }\end{array}$ & $\begin{array}{l}\text { Small family groups } \\
\text { (3-10 individuals) }\end{array}$ & $\begin{array}{l}\text { Freshwater } \\
\text { systems }\end{array}$ & Fish, crustaceans & $\begin{array}{l}4-7 \mathrm{~kg} \\
\text { Developed webbing on } \\
\text { paws }\end{array}$ \\
\hline $\begin{array}{l}\text { Lontra } \\
\text { canadensis }\end{array}$ & North America & $\begin{array}{l}\text { Small family groups } \\
\text { (3-10 individuals) }\end{array}$ & $\begin{array}{l}\text { Freshwater and } \\
\text { coastal habitats }\end{array}$ & $\begin{array}{l}\text { Fish, mollusks, } \\
\text { crustaceans }\end{array}$ & $\begin{array}{l}8-11 \mathrm{~kg} \\
\text { Developed webbing on } \\
\text { paws }\end{array}$ \\
\hline Lontra felina & $\begin{array}{l}\text { Pacific coast } \\
\text { of South } \\
\text { America }\end{array}$ & Solitary & $\begin{array}{l}\text { Rocky coastal } \\
\text { habitats }\end{array}$ & Mollusks, crustaceans & $\begin{array}{l}3-6 \mathrm{~kg} \\
\text { Developed webbing on } \\
\text { paws }\end{array}$ \\
\hline $\begin{array}{l}\text { Lontra } \\
\text { longicaudis }\end{array}$ & $\begin{array}{l}\text { Central and } \\
\text { South America }\end{array}$ & Solitary & $\begin{array}{l}\text { Freshwater } \\
\text { systems }\end{array}$ & $\begin{array}{l}\text { Fish, crustaceans, } \\
\text { small mammals, } \\
\text { birds, reptiles, } \\
\text { amphibians, } \\
\text { invertebrates }\end{array}$ & $\begin{array}{l}10-14 \mathrm{~kg} \\
\text { Developed webbing on } \\
\text { paws }\end{array}$ \\
\hline Lontra provocax & $\begin{array}{l}\text { Chile, South } \\
\text { America }\end{array}$ & Solitary & $\begin{array}{l}\text { Freshwater and } \\
\text { coastal habitats }\end{array}$ & $\begin{array}{l}\text { Fish, mollusks, } \\
\text { crustaceans }\end{array}$ & $\begin{array}{l}5-10 \mathrm{~kg} \\
\text { Developed webbing on } \\
\text { paws }\end{array}$ \\
\hline Lutra lutra & $\begin{array}{l}\text { From Europe } \\
\text { to Korea }\end{array}$ & Solitary & $\begin{array}{l}\text { Freshwater and } \\
\text { coastal habitats }\end{array}$ & $\begin{array}{l}\text { Fish, crustaceans, } \\
\text { small mammals, } \\
\text { birds, reptiles, } \\
\text { amphibians, } \\
\text { invertebrates }\end{array}$ & $\begin{array}{l}4-11 \mathrm{~kg} \\
\text { Developed webbing on } \\
\text { paws }\end{array}$ \\
\hline Lutra sumatrana & Southeast Asia & Solitary & $\begin{array}{l}\text { Freshwater } \\
\text { systems }\end{array}$ & $\begin{array}{l}\text { Fish, crustaceans, } \\
\text { small mammals, } \\
\text { birds, reptiles, } \\
\text { amphibians, } \\
\text { invertebrates }\end{array}$ & $\begin{array}{l}5-8 \mathrm{~kg} \\
\text { Developed webbing on } \\
\text { paws }\end{array}$ \\
\hline $\begin{array}{l}\text { Lutrogale } \\
\text { perspicillata }\end{array}$ & $\begin{array}{l}\text { India and } \\
\text { Southeast Asia }\end{array}$ & $\begin{array}{l}\text { Large family groups } \\
\text { (up to } 30 \\
\text { individuals) }\end{array}$ & $\begin{array}{l}\text { Freshwater and } \\
\text { coastal habitats }\end{array}$ & $\begin{array}{l}\text { Fish, crustaceans, } \\
\text { small mammals, } \\
\text { birds, reptiles, } \\
\text { amphibians, } \\
\text { invertebrates }\end{array}$ & $\begin{array}{l}7-10 \mathrm{~kg} \\
\text { Developed webbing on } \\
\text { paws }\end{array}$ \\
\hline $\begin{array}{l}\text { Pteronura } \\
\text { brasiliensis }\end{array}$ & South America & $\begin{array}{l}\text { Medium family } \\
\text { groups (5-15 } \\
\text { individuals) }\end{array}$ & $\begin{array}{l}\text { Freshwater } \\
\text { systems }\end{array}$ & Fish & $\begin{array}{l}24-34 \mathrm{~kg} \\
\text { Developed webbing on } \\
\text { paws }\end{array}$ \\
\hline
\end{tabular}

Note. Species in bold have no recorded observations of stone handling behavior yet. 


\section{Stone Handling in Otters}

SH has been observed in wild and captive otters (see supplementary video by CT of captive Aonyx cinereus practicing a form of $\mathrm{SH}$ ), although the form and distribution of this behavior across otter species is still unknown, providing the impetus for this report. A recent study conducted by Allison and colleagues (2020) presents the first in-depth investigation of one specific type of SH behavior ('rock juggling') in otters. These authors examined rock juggling in two species of captive otters (Lutrogale perspicillata and Aonyx cinereus) across three zoological institutions in the UK. The authors did not find any sex differences in rock juggling in either of the otter species but did find that rock juggling frequency decreased with age in mature individuals and increased with age in elderly otters. Similar to some of the theoretical approaches to macaques (Nahallage \& Huffman, 2007), Allison and colleagues (2020) hypothesized that rock juggling may aid motor development in young otters and/or prevent cognitive decline in older otters. Furthermore, the authors report that otters juggled significantly more before feeding than after feeding. They interpret this finding as suggesting that rock juggling behavior in otters may be a misdirected feeding behavior, as has also been suggested for some species of macaques (Huffman \& Nahallage, 2007; Leca et al., 2008; Pellis, 1991). Whilst Allison et al. (2020) provided the first in-depth investigation into rock juggling in two species of otters, an overview of the general distribution of this and other SH behaviors across otter species is still missing; this would, however, be useful to target further in-depth investigations into SH in otters.

\section{Figure 1}

Artistic Rendition by M.B. of an Otter Practicing Stone Handling Behavior

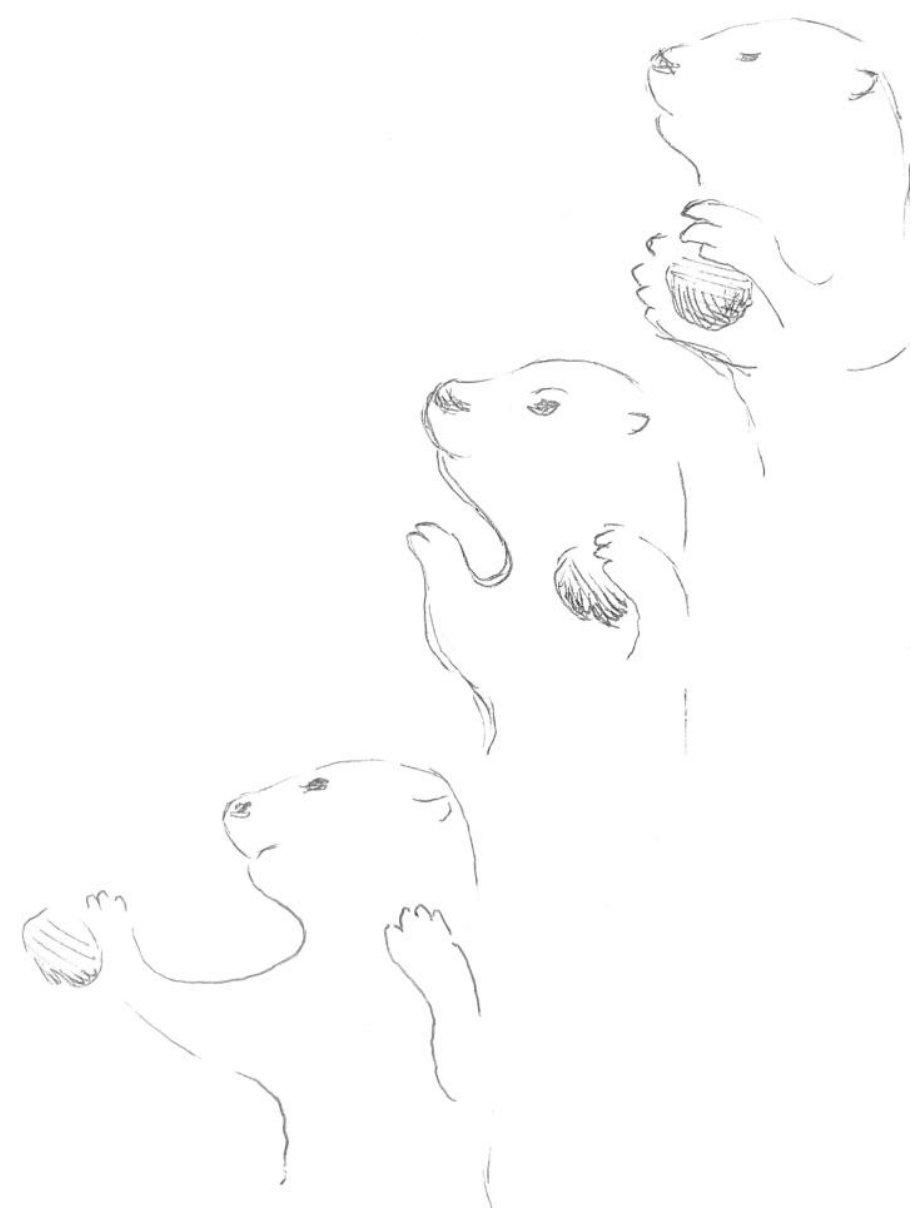




\section{Scope of the report}

The aim of this short report was to examine the distribution of SH across otter species both in the wild and in captivity, and therefore to provide the first database of accounts of SH across otter species as a starting point for guided in-depth exploration of the $\mathrm{SH}$ phenomenon in otters.

Our first step was to conduct a literature review on reports of SH in otters. The search engines: Google scholar and Web of Science, alongside a private database of relevant literature available to otter specialists were searched by EB and MB between June 2019 and April 2020. The search terms: 'otter stone handling behavior,' 'otter stone play,' 'otter stone tool-use,' and 'otter stone manipulation' were used. The only literature we were able to find using this method described the stone tool-use of Enhydra lutris (see above) and the study on 'rock juggling' in otters described above (Allison et al., 2020). No other reports of SH in otters were found. To continue examining the distribution of SH in otters, MB (a specialist in the field of otter behavior) personally contacted other otter specialists through email, messages, in person at conferences and on online forums for any reports of observations of SH in their studied populations and species of otters (all otter species were targeted this way).

\section{Method}

To conduct our first overview of the extent of otter SH, MB contacted otter specialists to enquire if they had ever seen any of their studied species practicing SH. Specifically, the specialists were asked whether they had seen any of their subjects: "manipulating stones in non-instrumental ways," roughly following the definition of the behavior provided by Leca et al., 2011: "spontaneous stone-directed noninstrumental manipulative behavior" (p. 61). If the researchers answered 'yes,' we then asked them whether the otters they observed had been in captivity or in the wild and to provide a very brief description of the behavior they observed. We asked for all accounts to be written and provided by email or message. All the researchers agreed to their observations being included in this report and are mentioned in the acknowledgments section. Following this method, we collected several anecdotal observations of SH across species. A summary of the observations is provided in Table 2.

Although we asked the researchers to be as descriptive as possible, it is important to note here that these are all anecdotal accounts of SH in the populations - intended to be a first overview of the extent of SH in otters - and no explicit studies or observations were carried out prior or during the data collection for this report. Therefore, although we are confident in the observations compiled in Table 2, follow up studies are required for further details. In coding for rock juggling, we followed the definition provided by Allison et al. (2020) in which rock juggling is defined as: "fast, erratic movements that pass an object between the forepaws and sometimes the mouth" (p. 2).

We asked researchers only about handling behaviors with stones, as this seems to be a crucial aspect of stone handling behavior (see also definition by Leca et al., 2011). As the aim of this short report was to provide a first overview of the extent of SH behavior across otter species, and to encourage the specialists to answer within a certain timeframe, only a binary (yes/no) response was required from the contacted researchers. We did not ask any further details other than a brief description of the behavior (as this was beyond the scope of this particular report).

\section{Results}

\section{Stone Handling in Otters}

SH was anecdotally reported in 10 out of the 13 known species of otters (see Table 2). The three species for which anecdotal evidence of SH behavior was not reported were Lutra sumatrana (hairynosed otter), Aonyx congicus (Congo clawless otter) and Lontra provocax (southern river otter). We received no reports on these species, perhaps due to the fact that there are very few sightings of Lutra sumatrana, Aonyx congicus and Lontra provocax in nature and even fewer are found in captivity. This 
should not, however, be taken as evidence for an absence of SH in these species in general (these might be false negatives). Indeed, we received one report of a young, captive Aonyx congicus showing SH-type behaviors with a plastic bottle cap, which we did not include in Table 2 as it was not directed towards stones. However, this report potentially suggests that one of the remaining species may also practice stone handling (although this remains to be confirmed).

Table 2

Observations of SH Behavior Across Wild and Captive Otters

\begin{tabular}{|c|c|c|c|}
\hline Species & Behavior Description & Country & Captive or Wild \\
\hline Aonyx capensis & Rock juggling and stone rolling on other stones & $\begin{array}{l}\text { Gabon, Cameroon, South } \\
\text { Africa \& DRC }\end{array}$ & Captive \\
\hline Aonyx cinereus & Rock juggling & UK & Captive \\
\hline Enhydra lutris & $\begin{array}{l}\text { Repeatedly drops stone in water and retrieves it; } \\
\text { rock juggling }\end{array}$ & USA & Captive \\
\hline $\begin{array}{l}\text { Hydrictis } \\
\text { maculicollis }\end{array}$ & $\begin{array}{l}\text { Passes stone back and forth from mouth to paws } \\
\text { and between paws and on other stones }\end{array}$ & USA & Captive \\
\hline Lontra canadensis & $\begin{array}{l}\text { Repeatedly drops stone in water and retrieves it, } \\
\text { then juggles stone in hands and on belly }\end{array}$ & USA & Captive \\
\hline Lontra felina & Rock juggling and juggling other stones & Brazil & Captive \\
\hline Lontra longicaudis & Rolling stones on the belly & Mexico & Captive \\
\hline Lutra lutra & $\begin{array}{l}\text { Repeatedly drops stone in water and retrieves it; } \\
\text { rock juggling; and rolls stones on other standing } \\
\text { stones }\end{array}$ & UK & Wild \& Captive \\
\hline $\begin{array}{l}\text { Lutrogale } \\
\text { perspicillata }\end{array}$ & Rock juggling & India & Wild \\
\hline $\begin{array}{l}\text { Pteronura } \\
\text { brasiliensis }\end{array}$ & Rock juggling & Brazil, USA & Wild \& Captive \\
\hline
\end{tabular}

Overall, our findings suggest that the majority of known otter species practice some form of SH. Many of the SH reports described the otters 'playing' with the stones by rolling them across their body or between their paws (similarly to what some researchers described as 'juggling,' see also recent report by Allison et al., 2020), rolling the stones on other standing stones, and dropping stones in the water and then retrieving them (see supplementary video and Figure 1).

\section{Discussion}

Our survey resulted in several anecdotal observational accounts of SH in otters. Currently, the majority (10 out of 13) of known species of otters demonstrated positive, albeit anecdotal, evidence for $\mathrm{SH}$. It is possible that the lack of reports of the behavior for the remaining three species may be false negatives, due to the rarity of general observations of these species both in the wild and captivity. These three species (Lutra sumatrana, Aonyx congicus, Lontra provocax) have been observed rarely due to the fact that they are elusive in the wild and inhabite countries that are difficult and/or dangerous to access for researchers. Furthermore, Lontra provocax is not currently found in captivity and only very few Lutra sumatrana and Aonyx congicus are found in captivity (unfortunately we were unable to communicate with the institutions that house these otters, and were able to find only one report of an Aonyx congicus showing SH-type behaviors with a plastic bottle cap). Overall, however, our findings suggest that SH is 
present in most otter species, similar to $\mathrm{SH}$ in macaques. This finding also suggests that otters might have a genetic predisposition for $\mathrm{SH}$ (although this remains to be further investigated).

Only one formal study of SH has been carried out in otters (Allison et al., 2020). Allison et al. (2020) provide an ethogram of the rock juggling behaviors they observed in two species of otters (Lutrogale perspicillata and Aonyx cinereus). Using the observational and anecdotal reports provided by the researchers in this report, and the ethogram provided by Allison and colleagues (2020), some overlap between macaque and otter SH can be identified. For example, both otters and macaques have been described to roll stones on other stones, as part of SH and rock juggling. However, follow-up studies should examine in more detail the ethograms of the otter species identified in this study for further similarities and differences to be identified.

Future research on $\mathrm{SH}$ in otters should focus on replicating the observations compiled for this study, and conducting systematic and more detailed studies into the context, frequency, and types of SH observed in wild and captive otters to create an ethogram and extended distribution table of SH across otter species (e.g., Allison et al., 2020). Furthermore, experimental studies such as the one by Allison et al. (2020) should be conducted with captive otters to determine this ability in different captive species. The aim of our short report was to describe the extent of otter SH behavior across species and provide a foundation for interested researchers to continue studying this behavior in otters and other animals. Investigating $\mathrm{SH}$ in otters can provide insight into this behavior in other species, and into the development of foraging competence, the motivation underlying tool-use, and potentially even the evolution of some aspects of human material culture (Pelletier et al., 2017).

\section{Acknowledgements}

The authors are very grateful to Rachelle Daigneault, David Rowe-Rowe, Vania Carolina Fonseca, Pablo Hernandez, David Webb, Miranda Fink, Ruth Steel Mock, Christine Montgomery, Andrea Standridge, Katrina Wilbanks, Tammy Schmidt, Atul Borker, Elie Caruso, Rinaldo Verdi Bruñol, Carol Bennetto, Jason Palmer, Rita Chapman, Alesandra Bez Birolo, Oldemar Cavalho-Junior, Shawn Larson, Traci Belting, Tamara de Juana and Jo Gaweda for providing information on SH in their study populations. We also thank the D'Idlers and Christa O. Finkenwirth. EB \& CT are supported by the Institutional Strategy of the University of Tübingen (Deutsche Forschungsgemeinschaft, ZUK 63). At the time of writing, CT was also supported by the European Research Council under the European Union's Horizon 2020 research and innovation programme for the ERC STONECULT starting grant (grant agreement No. 714658).

\section{References}

Allison, M. L., Reed, R., Michels, E., \& Boogert, N. J. (2020). The drivers and functions of rock juggling in otters. Royal Society Open Science, 7(5), 1-14. https://doi.org/10.1098/rsos.200141

Bandini, E., \& Tennie, C. (2018). Naive, captive long-tailed macaques (Macaca fascicularis fascicularis) fail to individually and socially a tool-use behavior. Royal Society Open Science,5(5), 171826. https://doi.org/10.1098/rsos.171826

Duplaix, N., \& Bandini, M. (2016). We love otters. Four Corners Institute.

Fujii, J. A., Ralls, K., \& Tinker, M. T. (2015). Ecological drivers of variation in tool-use frequency across sea otter populations. Behavioral Ecology, 26(2), 519-526. https://doi.org/10.1093/beheco/aru220

Fujii, J. A., Ralls, K., \& Tinker, M. T. (2017). Food abundance, prey morphology, and diet specialization influence individual sea otter tool use. Behavioral Ecology, 28(5), 1206-1216. https://doi.org/10.1093/beheco/arx011

Gunst, N., Huffman, M., \& Leca, J. B. (2007). Japanese macaque cultures: inter-and intra-troop behavioral variability of stone handling patterns across 10 troops. Behavior, 144(3), 251-281. https://doi.org/10.1163/156853907780425712

Haslam, M., Fujii, J., Espinosa, S., Mayer, K., Ralls, K., Tinker, M. T., \& Uomini, N. (2019). Wild sea otter mussel pounding leaves archaeological traces. Scientific Reports, 9(1), 1-11. https://doi.org/10.1038/s41598-01939902-y 
Huffman, M. A., \& Quiatt, D. (1986). Stone handling by Japanese macaques (Macaca fuscata): Implications for tool use of stone. Primates, 27(4), 413-423. https://doi.org/10.1007/BF02381887

Huffman, M., \& Nahallage, C. (2007). Acquisition and development of stone handling behavior in infant Japanese macaques. Behavior, 144(10), 1193-1215. https://doi.org/10.1163/156853907781890959

Kruuk, H. (2006). Otters: Ecology, behavior and conservation. Oxford University Press.

Leca, J., Gunst, N., \& Huffman, M. A. (2008). Food provisioning and stone handling tradition in Japanese macaques: A comparative study of ten troops. American Journal of Primatology, 70(8), 803-813. https://doi.org/10.1002/ajp.20551

Leca, J. B., Gunst, N., \& Huffman, M. A. (2011). Complexity in object manipulation by Japanese macaques (Macaca fuscata): A cross-sectional analysis of manual coordination in stone handling patterns. Journal of Comparative Psychology, 125(1), 61-71. https://doi.org/10.1037/a0020868

Nahallage, C. A. D., \& Huffman, M. A. (2007). Age-specific functions of stone handling, a solitary-object play behavior, in Japanese macaques (Macaca fuscata). American Journal of Primatology, 69(3), 267-281. https://doi.org/10.1002/ajp.20348

Nahallage, C. A. D., \& Huffman, M. A. (2012). Stone handling behavior in rhesus macaques (Macaca mulatta), a behavioral propensity for solitary object play shared with Japanese macaques. Primates, 53(1), 71-78. https://doi.org/10.1007/s10329-011-0279-x

Pelletier, A. N., Kaufmann, T., Mohak, S., Milan, R., Nahallage, C. A. D., Huffman, M. A., Gunst, N., Rompis, A., Wandia, I. N., \& Agung, I. G. (2017). Behavior systems approach to object play: Stone handling repertoire as a measure of propensity for complex foraging and percussive tool use in the genus Macaca. Animal Behavior \& Cognition, 4, 455-473. https://doi.org/10.26451/abc.04.04.05.2017

Pellis, S. M. (1991). How motivationally distinct is play? A preliminary case study. Animal Behavior 42(5), 851853. https://doi.org/10.1016/S0003-3472(05)80129-0

Perry, J. A. (2012). Variation in the frequency of tool use across and within sea otter (Enhydra lutris) populations [unpublished doctoral dissertation]. UC Santa Cruz.

Power, T. G. (1999). Play and exploration in children and animals. Psychology Press.

Riedman, M., \& Estes, J. A. (1990). The sea otter (Enhydra lutris): Behavior, ecology, and natural history. Biological Report (USA), 90(14), 1-32.

Tan, A. W. Y. (2017). From play to proficiency: The ontogeny of stone-tool use in coastal-foraging long-tailed macaques (Macaca fascicularis) from a comparative perception-action perspective. Journal of Comparative Psychology, 131(2), 89-114. https://doi.org/10.1037/com0000068

van Horik, J. O., \& Madden, J. R. (2016). A problem with problem solving: Motivational traits, but not cognition, predict success on novel operant foraging tasks. Animal Behavior, 114, 189-198. https://doi.org/10.1016/j.anbehav.2016.02.006 